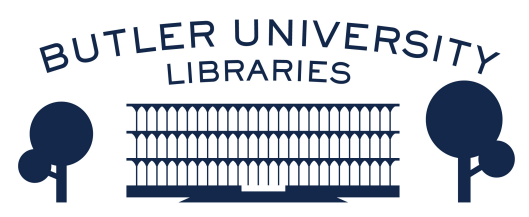

Journal of Hindu-Christian Studies

Volume 19

Article 7

January 2006

\title{
Listening to the Snake; or, On Having a Spine
}

Jeffrey J. Kripal

Follow this and additional works at: https://digitalcommons.butler.edu/jhcs

Part of the Religion Commons

\section{Recommended Citation}

Kripal, Jeffrey J. (2006) "Listening to the Snake; or, On Having a Spine," Journal of Hindu-Christian Studies: Vol. 19, Article 7.

Available at: https://doi.org/10.7825/2164-6279.1362

The Journal of Hindu-Christian Studies is a publication of the Society for Hindu-Christian Studies. The digital version is made available by Digital Commons @ Butler University. For questions about the Journal or the Society, please contact cbauman@butler.edu. For more information about Digital Commons @ Butler University, please contact digitalscholarship@butler.edu. 


\title{
Listening to the Snake or On Having a Spine
}

\author{
Jeffrey J. Kripal \\ Rice University
}

For the serpent was wiser than any of the animals that were in Paradise .... But the creator cursed the serpent, and called him devil.

The Testimony of Truth ${ }^{\text {lvi }}$

Over it [the svayambhu-lingam] shines the sleeping Kundalini, fine as the fibre of the lotus-stalk. She is the worldbewilderer, gently covering the mouth of Brahma-dvara [the hollow at the top of the svayambhu-lingam] by Her own.

Verse 10 of the Sat-Cakra-Nirupana ${ }^{\text {Ivii }}$

THE western prohibition of reflection on what we call today "religion" begins not with a banned scholarly monograph or a taunted academic, but with a myth about a transgressive desire for mature moral knowledge and a subsequent sexual emotion, namely, Adam and Eve's shameful sense of being naked after accepting the serpent's gift of the knowledge of good and evil. Elsewhere, I have explored some of the ways that western religious thought has sexualized this foundational myth in order to take up this gnosis as my own and explore the problems and promises of sexual desire, gender difference, sexual orientation, love, mortality, and-above all-the inescapably transgressive nature of radical thinking about religion in the contemporary academy. ${ }^{\text {lvii }}$

The present meditation is an extension of that earlier project, extended here into the contemporary Indological discussion of book banning in India and the supposedly "western" nature of radical thinking about religion and sexuality. I offer these thoughts as constructive transgressions, that is, as intentional and positive provocations that might helps us to begin

JEFFREY J. KRIPAL is the J. Newton Rayzor Professor of Religious Studies and Chair of the Department of Religious Studies at Rice University, U.S.A. He is the author of The Serpent's Gift: Gnostic Reflections on the Study of Religion (Chicago, 2006), Roads of Excess, Palaces of Wisdom: Eroticism and Reflexivity in the Study of Mysticism (Chicago, 2001) and Kali's Child: The Mystical and the Erotic in the Life and Teachings of Ramakrishna (Chicago, 1995). He has also co-edited volumes with Rachel Fell McDermott on a popular Hindu goddess, Encountering Kali: In the Margins, at the Center, in the West (California, 2003); with G. William Barnard on the ethical critique of mystical traditions, Crossing Boundaries: Essays on the Ethical Status of Mysticism (Seven Bridges, 2002); and with T.G. Vaidyanathan of Bangalore, India, on the dialogue between psychoanalysis and Hinduism, Vishnu on Freud's Desk: A Reader in Psychoanalysis and Hinduism (Oxford, 1999). His areas of interest include the comparative erotics and ethics of mystical literature, American counter-cultural translations of Hindu and Buddhist Tantric traditions, and the history of Western esotericism from ancient gnosticism to the New Age. He is presently finishing a history of the Esalen Institute, the human potential center in Big Sur, California, entitled Esalen: America and the Religion of No Religion (Chicago, 2007). 
thinking beyond the methodological solipsisms and cultural essentialisms in which these "controversies" always seem to be locked, as if Indian authors never had a thought about sex and religion, or as if there were no talking, tempting snakes in Indian lore.

I am hardly alone in turning to the Garden of Eden to begin a project about the religious mysteries of human sexuality. Numerous other biblical critics, historians of Christianity and Judaism, and comparativists have heard more or less the same thing in that hissing snake. They have heard sex. ${ }^{\text {lix }}$ I want to engage the story in a slightly different way here, however, as I believe this early Hebrew myth is particularly instructive for us in the present context. Basically, I want to engage it as a modern midrash or parable that can help us confront some of the epistemological and theological dilemmas that the modern study of religion poses for any traditional religious system, that is, the dilemma defined by the human desire to know and to not know the truth about sexuality and religion. Hence the hissing serpent (who knows), the lovely couple (who want to know), and the jealous and rather petty father god (who wants, well, to stop them from knowing). We can, I hope, recognize all these characters in our present circumstances. It's a depressingly stubborn story.

Certainly the history of writing out the sexual dimensions of religious experience within a tradition like Christianity bears out both this erotic desire to know and this "divine" preference for sexual and moral ignorance. We could proceed from here in any number of directions for hundreds, indeed thousands, of pages. We could examine, for example, the reports of "deviant" sexual acts so prominently featured in attacks against heresy throughout the history of Christianity, from early claims that Christian Gnostics used sexual fluids as sacramental substances to early modern European concern over witchcraft, which was often expressed through sexual motifs such as the witch's intercourse with the devil, the physical nature of Satan's semen, stolen penises, and the occult orgy. ${ }^{1 \mathrm{x}}$ Or we could note that those two paradigmatic Catholic mystics of the erotic, Sts. Teresa of Avila and John of the
Cross, both wrote under the threatening gaze of the Inquisition. John was actually jailed at one point in his life, and Teresa, the only female theologian to be published in late sixteenthcentury Spain, had to write in code to escape the inquisitorial censors who were so anxious to contain ecstasies and visions of all sorts, 'but particularly those of women. ${ }^{\text {Ixi }}$

Of course, the problem is much broader than the erotic. Most generally put, the problem is the transgressive nature of thought itself, particularly when it is applied to religion. Such thought, of course, is always overflowing, ignoring or offending the imaginary boundaries of the particular socio-religious system in which it erupts (or hisses). Is this not precisely what it means to be "creative," to be "original," to write "at the cutting edge" of some discipline or tradition? And is not this literally what it means to be an author, that is, to be one's own authority? To be one's own authority, of course, is often more or less equivalent to challenging or denying the authority of those in political and religious power. It is at once a political and an ethical act of real-world consequence. Little wonder, then, that acts of censorship and persecution have been replayed a thousand times in the modern world in almost every field of study, where intellectuals are routinely harassed, threatened, occasionally even chased out of their professions or countries by those who cannot stand what Virginia Woolf once called "the habit of freedom and the courage to write exactly what we think." To think radically, "to the root," is to transgress.

Why do we always need reminded of this? Have we forgotten that much of the American intellectual culture of the 40s and 50s was in fact dominated by European exiles, writers who had fled fascist regimes in Europe, particularly Nazi Germany, to protect their intellectual freedoms and preserve their lives? Have we also forgotten the gross censorship campaigns initiated here, for example, the McCarthy paranoia of the 50s and its attempted purges of the American academy and entertainment industry as somehow "communist" and "anti-American"?

Similar patterns go back to the beginning of the modern study of religion, 
which has always had to struggle against the religions in order to defend its right to study them in full freedom. David Friedrich Strauss, for example, inspired by German mystical thought, attempted to understand Jesus as a pantheistic mystic in his pioneering The Life of Jesus Critically Examined (1835). In the process, he also denied the traditional literal understandings of the resurrection and miracle stories. The result? He found it impossible to get a permanent professorship. "His name was anathema in the German universities," Peter Hodgson tells us. Three times his name came up for positions. The third time it was accepted, but only until a public outcry forced a referendum vote "in which the citizens of Zürich supported a petition revoking the call by a vote of 39,225 to 1,048." "xii

Female scholars have probably suffered far more than the men, as they, having suffered through their own micro-histories of culturally sanctioned misogyny and religiously authorized oppression, have generally been much more ready to see and critically analyze the gendered and sexual dimensions of Christianity, or any other religion for that matter. Jane Schaberg certainly suffered more grievously than most for her The Illegitimacy of Jesus. The book's thesis that the mythology of the virgin birth was a later "spin" on an original illegitimacy story attracted considerable scorn from both religious and scholarly circles. Her own Vice President for Academic Affairs, who one would think would defend academic freedom and not judge truth by polls, stated that "I would say $99 \%$ of the people at this university disagree with her." back to Strauss's referendum vote, I suppose. Vicious hate-mail and phone calls flooded Schaberg's office and campus, calling her "whore, feminazi, queen of crapola, pseudointellectual, delusional, bitch, blasphemer, heretic, a spiritual cancer, Satanic, lesbian, and sicko." "xiv These same people asked for her resignation, insisted that she had no place on the faculty of a Catholic institution, and, in a couple of cases, called for her death. And why? Because she had the audacity to point out the obvious (that Joseph was not Jesus's father) and ground an obvious biological skepticism about a virginal birth in some very solid New Testament scholarship. The feminist theologians Chung Hyun-Kung in Korea, Rosemary Radford Ruether, and Elisabeth Schüssler-Fiorenza, to name just a few, have all suffered similarly from right-wing, anti-feminist Christian groups. Feminists thus now routinely and rightly speak of a "backlash," in essence, another kind of whipping.

This depressing list of offended religious communities and harassed scholars could be extended for a very long time, and this across virtually every religious tradition in both the West and Asia, from the study of Sikhism and the Bahais, to the study of Islam and Native Americans. In truth, although this historical phenomenon of prohibition always takes on the local colors and nuances of its historical contexts, it appears to transcend these same contexts as an extremely common, if not universal, feature of the history of study of religion.

To take our own present situation, certainly the postcolonial context in which we think and write now within American Indology is terribly important and has its own deep truths that we must acknowledge and work throughwe are not innocent-but the universality and ancient nature of religious prohibitions against open discussions of sexuality and religion should warn us against any facile reduction of the present climates of offense to colonial or postcolonial processes. Yes, these are indeed crucial, but something else is also at work here, something much more fundamental to religion itself, something involving the anxious attempt to control power, authority and meaning itself.

It is often claimed in these contexts of controversy, as if this somehow settles the matter, that the critical study of religion is a "western" project, and that it was inspired largely, if not entirely, by Christian categories and institutional histories. Yes. Christianity contains within itself a very radical critique, even rejection, of religion itself, at least if we define "religion" as that set of beliefs and social, dietary and ritual customs inherited from one's cultural tradition or ethnic group (which, of course, well describes' much of the Hindu caste system and its purity codes). Perhaps, then, it is not surprising at all that the critical study of 
religion arose within European Christianity. Nor should it surprise us, though, that the same discipline has been profoundly, and perhaps even more deeply, formed by Jewish intellectuals who sat uncomfortably on the "outside" of normative European Christian culture (outsiders, after all, often see things more clearly than insiders). Consequently, to this day, the overwhelming majority of critical scholarship is still directed exclusively at either Christian or Jewish sources and is performed by Christian or Jewish intellectuals.

The study of Indian religions, on the other hand, has been-both institutionally and historically-little more than a footnote or appendix to this project, and it remains largely derivative in terms of actual theory. So the postcolonial critique of Indology (itself a development of Marxist theory) is perfectly correct to note that the study of religion derived from "western" religious sources and that it was historically connected to colonial histories. It is perfectly wrong, however, to suppose that this means that the study of religion goes easy on Christianity or Judaism, or that it is aimed primarily at non-western traditions. The exact opposite is in fact much closer to the historical truth, and even the colonial study of Hinduism was often designed to delegitimate and deconstruct not Indian or Hindu, but European Christian culture. ${ }^{\mathrm{Xv}}$ The discipline has, I think, been grossly misread on this issue, or, perhaps better, read only partly.

So it seems rather dysfunctional (and tellingly defensive) to dismiss the modern study of religion through the correct but too easy labels of "Western" or "Christian." A much more positive and creative approach might begin by noting that Christianity is hardly alone in possessing its own deconstructions of religion. Indeed, as already noted, many of the most important critics of religion (Marx, Freud and Durkheim) were in fact Jewish intellectuals. Similarly, Buddhism in its origins is largely a critique and rejection of Vedic Brahmanism, as is, for that matter, much of classical Hinduism. From the Upanisadic deconstruction of Vedic ritual and the spiritual reduction of the gods to states of consciousness, through the radical, if often implicit, social critiques of the bhakti movement (Kabir seems especially radical ${ }^{\mathrm{lxvi}}$ ) and the metaphysical denial of theism within Advaita Vedanta, to the erotic transgressions and purity code violations of the Tantric traditions, Indian religion is in fact fantastically rich with dramatic examples of the religious criticism of religion.

So why not develop a modern critical study of Indian religion from the categories and histories of this cultural richness? Why not listen for the serpent here? I recognize that Advaita Vedanta has already functioned as an implicit method of much study, particularly in the late nineteenth and early twentieth centuries. But although its critical pay-offs have been significant, they have hardly been exhaustive. Most problematically, the particular gaze Advaita Vedanta produces is a very restricted and abstracted one. So much (like the body) is left out, or simply denied as non-existent. It wants to see the serpent as nothing more than a rope. This will not do, not at least for a discipline that values hissing and loves snakes. Perhaps, then, it is now time to turn to more promising and useful Indian thought forms. Perhaps it is time to begin turning the rope back into a snake.

Hence the Tantra. Here, at least, we have a real Indian analogue to the "western" or "Christian" study of religion, and one that could easily match the latter in both its intellectual boldness and its essential scandal. There are many ways to frame this cross-cultural resonance. The one I have adopted in much of my writing proceeds by positing a particular kind of cross-cultural resonance or "echo" between psychoanalysis, as the "Tantra" of the West, and Tantra, as the "psychoanalysis" of South Asia. lxvii Here at least, the Tantric traditions become a particularly rich resource for cross-cultural dialogue and theory building. ${ }^{\text {lxviii }}$ I recognize fully-and from personal experience-that there are real political and practical problems with such a suggestion, but, pace Foucault, politics and truth are not at all the same thing, a controversy is hardly equivalent to a mature conclusion, and controversies often necessarily precede real theoretical breakthroughs. 
Serendipitously, the Tantric traditions even have a gnostic serpent of their own, in this case the kundalini, that feminine snake coiled around the lingam at the base of the body whose movement through the cakras explicitly connects the anal and genital regions to the highest reaches of mystical rapture and contemplative breakthrough. Apparently, the ancient and medieval Indian writers and artists didn't need Freud to tell them that the spiritual and the sexual are organically, energetically, metaphysically related, or that the one could morph into the other through ascetic sublimation or erotic expression. The snake had told them that, and they listened well.

Put a different way, that is, in terms of a radical Christian theology, what I am trying to suggest through these little Gnostic and Tantric reflections is that the spirit and public institutions of our scholarship should resemble far more-if by no means exclusively or always - the freedom and transgressions of what is historically called "heresy" than they should represent the conservative concerns and prohibitions of religious orthodoxy. This is what I have called the serpent's gift of scholarship and have imagined as "gnostic." But we can just as easily imagine it as "Tantric," as I have here. Admittedly, such a gift is not always easy to accept, and many will reject it outright (or declare it to be a devil or an illusory rope). But it is a gift nonetheless. Through such a gnosis or jnana, we are gradually learning not to fear and demonize the serpent of our own sexualities. We are learning to listen to the snake.

It would be odd if we didn't. As spinal serpents that anatomically and neurologically connect the genitals to the brain (and viceversa), we all are that hissing snake. Who of us, after all, does not have a spine?

\footnotetext{
lvi The Testimony of Truth, 163, in James M. Robinson, general editor, The Coptic Gnostic Library: A Complete Edition of the Nag Hammadi Codices, vol. 5 (Leiden: Brill, 2000).
}

lvii Verse 10 of the Sat-cakra-nirupana, as translated and commented on in Arthur Avalon, The Serpent Power: The Secrets of Tantric and Shakti Yoga (New York: Dover Publications, 1974/1964), p. 346; the bracketed comments are my own but based on Avalon.

Iviii Jeffrey J. Kripal, The Serpent's Gift: Gnostic Reflections on the Study of Religion (Chicago: University of Chicago Press, 2006).

lix For a sampling of similar studies, see: David Biale, Eros and the Jews: From Biblical Israel to Contemporary America (Berkeley: University of California Press, 1997); Kristen E. Kvam, Linda S. Schearing, and Valerie H. Ziegler, eds. Eve \& Adam: Jewish, Christian, and Muslim Readings on Genesis and Gender (Indianapolis: Indiana University Press, 1999); David M. Carr, The Erotic Word: Sexuality, Spirituality, and the Bible (New York: Oxford University Press, 2003); Steven Greenberg, Wrestling with God and Men: Homosexuality in the Jewish Tradition (Madison: University of Wisconsin Press, 2004), 51.

${ }^{\mathrm{lx}}$ Walter Stephens, Demon Lovers: Witchcraft, Sex, and the Crisis of Belief (Chicago: University of Chicago Press, 2002).

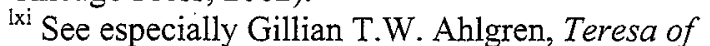
Avila and the Politics of Sanctity (Ithaca: Cornell University Press, 1996).

lxii Peter C. Hodgson, "Editor's Introduction," The Life of Jesus Critically Examined by David Friedrich Strauss (Ramsey, NJ: Sigler Press, 1994), xxxvi. lxiii For Schaberg's reflections on the aftermath of her work, see Schaberg, "Feminism Lashes Back:

Responses to the Backlash," Biblicon 3 (1999).

lxiv Ibid., 47.

${ }^{1 x v}$ For some sample discussions of this extremely common pattern, see: David Weir, Brahma in the West: William Blake and the Oriental Renaissance (Albany: SUNY, 2002); J. J. Clarke, Oriental Enlightenment: The Encounter Between Asian and Western Thought. London: Routledge, 1997); Arthur Versluis, American Transcendentalism and Asian Religions (New York: Oxford, 1993); and Raymond.Schwab, The Oriental Renaissance: Europe's Rediscovery of India and the East, 16801880 (New York: Columbia University Press, 1983). ${ }^{\text {Ixvi }}$ Purushottam Agrawal, "Seeking an Alternative to Religion Itself! The Sadhana (Pursuit) of Kabir," Thematology (Calcutta: Jodhapur University, n.d.). lxvii See, for example: "Shashibhushan Dasgupta's Lotus: Realizing the Sublime in Contemporary Tantric Studies," in Rachel Fell McDermott and Cynthia Ann Humes, eds., Breaking Boundaries with 
the Goddess: New Directions in the Study of Saktism. Essays in Honor of Narendra Nath Bhattacharyya (New Delhi: Manohar, forthcoming); "Teaching Hindu Tantrism With Freud: Psychoanalysis as Critical Theory and Mystical Technique," in Diane Jonte-Pace, ed., Teaching Freud in Religious Studies (New York: Oxford University Press, 2003): 213-237; "Kali in the Psychoanalytic Tradition: Or Why the Tantrika Is a Hero," in Rachel Fell McDermott and Jeffrey J.

Kripal, eds., Encountering Kali: In the Margins, at the Center, in the West (Berkeley: University of California Press, 2003): 196-222; "Re-membering a Presence of Mythological Proportions: Psychoanalysis and Hinduism," in William B. Parsons and Diane Jonte-Pace, eds., Mapping Religion and Psychological Studies: Contemporary Dialogues, Future Prospects (New York: Routledge Press, 2000): 254-279; "A Garland of Talking Heads for the Goddess: Some Autobiographical and Psychoanalytic Reflections on the Western Kali," in Alf Hiltebeitel and Kathleen Erndl, eds., Is the Indian Goddesses a Feminist? (Sheffield: Sheffield Academic Press, 2000): 239-268; and Kali's Child: The Mystical and the Erotic in the Life and Teachings of Ramakrishna (Chicago: University of Chicago Press, $1995 ; 2^{\text {nd }}$ ed., 1998).

Ixvilii The essentialisms are purely rhetorical. In historical fact, Tantric traditions have been active in the U.S. at least since the last quarter of the nineteenth century, and psychoanalysis is presently flourishing in Asia, particularly in China (personal communication, Sudhir Kakar, 18 December 2004). 